\title{
PENERAPAN MODEL PEMBELAJARAN SCIENTIFIC INQUIRY UNTUK MENINGKATKAN KEMAMPUAN LITERASI SAINS PESERTA DIDIK PADA SUB MATERI POKOK FLUIDA DINAMIS
}

\author{
Enden Suhila', Chaerul Rochman' ${ }^{1}$ dan Endah Kurnia Yuningsih ${ }^{1}$ \\ 1. Program Studi Pendidikan Fisika, Jurusan Pendidikan Matematika dan Ilmu \\ Pengetahuan Alam,Fakultas Tarbiyah dan Keguruan Universitas Islam Negeri Sunan \\ Gunung Djati Bandung \\ E-mail: endahkurnia@uinsgd.ac.id
}

\begin{abstract}
ABSTRAK
Tujuan penelitian ini untuk mengetahui keterlaksanaan proses pembelajaran dan peningkatan kemampuan literasi sains peserta didik dengan menggunakan model pembelajaran Scientific Inquiry pada sub materi pokok fluida dinamis. Data keterlaksanaan aktivitas guru dan peserta didik diperoleh melalui lembar observasi, sedangkan data kemampuan literasi sains peserta didik diperoleh melalui tes uraian Metode yang digunakan dalam penelitian ini adalah pre experiment. Penelitian dilakukan di MA Muhammadiyah Al-Furqon Tasikmalaya kelas XI IPA B. Sampel dalam penelitian sebanyak 28 peserta didik yang dipilih dengan menggunakan teknik random sampling. Hasil yang diperoleh dalam penelitian ini: (1) keterlaksanaan pembelajaran dengan menggunakan model pembelajaran Scientific Inquiry berkategori sangat baik; (2) kemampuan literasi sains peserta didik mengalami peningkatan. Besarnya peningkatan literasi sains semua aspek peserta didik dapat dilihat dari rata-rata $\mathrm{N}$-Gain peserta didik sebesar 0,67 berkategori sedang. Dengan demikian terdapat peningkatan kemampuan literasi sains peserta didik melalui model pembelajaran Scientific Inquiry pada materi fluida dinamis.
\end{abstract}

Kata kunci: Scientific Inquiry model of learning, Scientific Literacy, fluid dynamic.

\begin{abstract}
The purpose of study is to determine the feasibility of learning processes and increase science literacy skills of learners using 'Scientific Inquiry' model of learning on the fluid dynamic. Data katerlaksanaan activity of teacher and students is obtained through observation sheets, while data on the literacy skills of learners is obtained through the test description.The method used in this research is pre-experiment. The study was conducted in Muhammadiyah Al-Furqon senior high school Tasikmalaya class XI IPA-B. The sample in the study were 28 students who were selected using random sampling techniques. The results obtained in this study: (1) feasibility study by using 'Scientific Inquiry' model of learning is in very good category; (2) the literacy skills of learners sins increase in gain results. The magnitude of the increase scientific literacy of students can be seen from the average $N$-Gain learners of 0.67 categorized being. Thus there is increasing scientific literacy capability of learners through the 'Scientific Inquiry' model of learning in fluid dynamic.
\end{abstract}

Keywords: Scientific Inquiry model of learning, Scientific Literacy, fluid dynamic.

DOI: http://dx.doi.org/10.15575/jtlp.xxx.xxx

Received: xxxxxx ; Accepted: xxxxxx ; Published: $\operatorname{xxxxxxx}$ 


\section{PENDAHULUAN}

Menurut Program for Internasional Student Assesment (PISA) menyatakan bahwa tujuan pendidikan sains adalah untuk dapat memenuhi kebutuhan hidupnya dalam berbagai situasi. Dengan kompetensi itu, peserta didik akan mampu belajar lebih lanjut dan hidup di masyarakat yang saat ini banyak dipengaruhi oleh perkembangan sains dan teknologi. Dengan begitu, para peserta didik dapat berguna bagi dirinya sendiri dan masyarakat. Kompetensi itulah yang dimaksud sebagai literasi sains (Toharudin, Hendrawati dan Rusmana, 2011). Literasi sains menurut PISA adalah kemampuan untuk terlibat dengan masalah pengetahuan sains yang berhubungan dengan ide-ide berdasarkan bukti-bukti dalam rangka memahami ilmu pengetahuan sains juga sebagai warga negara yang reflektif (PISA, 2015).

Hasil wawancara dan observasi di MA Muhammadiyah Al-Furqon Tasikmalaya pada 08 Desember 2015. Data diperoleh guru masih mendominasi proses belajar mengajar di kelas dan sebagian besar dari peserta didik masih belum bisa menggunakan pengetahuan sains yang mereka miliki untuk memecahkan masalah yang berhubungan dengan fenomena alam yang terjadi dan peserta didik mengungkapkan bahwa peserta didik masih sulit memahami materi pembelajaran fisika baik teori ataupun penerapannya. Hasil observasi kegiatan pembelajaran di kelas diperoleh gambaran bahwa pada kegiatan awal tahap apersepsi dan motivasi guru masih kurang memicu peserta didik untuk berpikir berdasarkan fenomena kehidupan sehari-hari sehingga peserta didik kurang mampu mengaitkan pengetahuan yang diperoleh dengan fenomena kehidupan seharihari. Selain itu, kegiatan peserta didik dalam proses pembelajaran fisika yang diterapkan cenderung pasif. Peserta didik hanya sebatas duduk, mendengarkan penjelasan guru, mencatat kembali materi yang dipaparkan oleh guru. Sehingga memungkinkan peserta didik kurang terlatih untuk bertanya dan menjawab suatu pertanyaan yang berkaitan tentang fenomena alam, mengobservasi dan mempertimbangkan hasil observasi secara aktif. Hal inilah yang menyebabkan kemampuan literasi sains Indonesia masih rendah berdasarkan data terakhir PISA.

Berdasarkan pemaparan diatas untuk meningkatkan kemampuan literasi sains dapat dilakukan dengan berbagai upaya, untuk meningkatkan kemampuan literasi sains dengan melakukan kegiatan efisien, dimana guru harus merancang pembelajaran yang menyenangkan dan dapat menarik perhatian peserta didik. Salah satu model pembelajaran yang menyenangkan dan dapat menarik perhatian peserta didik yaitu model Scientific Inquiry.

Beberapa hasil penelitian yang menggunakan model pembelajaran Scientific Inquiry diantaranya: Menurut Ladachart, dan Yuenyong menyatakan bahwa Penyelidikan ilmiah (Scientific Inquiri) membantu dalam mengembangkan literasi sains. Ditandai dengan meningkatnya nilai tes yang dicapai peserta didik (Ladahchart dan Yuenyong, 2015). Menurut Hussain, et. al, dalam penelitiannya menunjukkan bahwa metode Scientific Inquiry merupakan suatu pengajaran yang siginifikan dibandingkan metode ceramah dalam mengajar fisika (Hussain, dkk., 2011). Menurut Lederman dengan menggunakan Scientific Inquiry, peserta didik mampu mengembangkan pertanyaanpertanyaan ilmiah, dan melakukan penyelidikan yang akan menghasilkan data (Lederman, 2009). Selain itu juga, menurut Wenning mengatakan bahwa kemampuan literasi sains dapat diketahui dengan mengukur kemampuan inquiri peserta didik. Kemampuan inquiri ini berarti kemampuan menyelidiki (Wenning, 2007).

Penyelidikan ilmiah (scientific inquiry) dapat membuat peserta didik mampu untuk melakukan investigasi dan mengartikulasikan penjelasan dalam hal konsep-konsep ilmiah (Grigg, dkk., 2013). Menurut penelitian Rahmawati menyatakan bahwa model pembelajaran Scientific Inquiry dapat meningkatkan kemampuan generik sains peserta didik pada materi Fluida Statis (Rahmawati, 2015), dan menurut Budiman menyatakan bahwa model pembelajaran Scientific Inquiry 
dapat meningkatkan keterampilan proses sains peserta didik pada materi pengukuran (Budiman, 2015).

Berdasarkan latar belakang masalah di atas, maka peneliti melakukan penelitian tentang penerapan model pembelajaran scientific inquiry untuk meningkatkan kemampuan literasi sains peserta didik pada sub materi pokok fluida dinamis.

Tujuan dari penelitian ini adalah untuk mengetahui keterlaksanaan model pembelajaran Scientific Inquiry dan peningkatan kemampuan literasi sains peserta didik setelah diterapkan model pembelajaran Scientific Inquiry pada sub materi pokok fluida dinamis.

\section{METODE PENELITIAN}

Metode yang digunakan dalam penelitian ini pre-eksperimen. Penelitian ini hanya dilakukan pada kelas eksperimen tanpa adanya kelompok pembanding (kelas kontrol). Desain yang digunakan dalam penelitian ini adalah one-group pretest-posttest design. Representasi desain onegroup pretest-posttest seperti dijelaskan dalam Sugiyono (Sugiyono, 2013). Jenis data yang diambil dari penelitian ini adalah data kuantitatif dan kualitatif yang diuraikan sebagai berikut:

\section{Data kuantitatif}

Data kuantitatif adalah data yang berhubungan dengan angka atau bilangan yang diperoleh dari hasil tes evaluasi yaitu berupa data mengenai presentase keterlaksanaan pembelajaran dan skor kemampuan literasi melalui penerapan model pembelajaran Scientific Inquiry pada materi fluida dinamis, yang diperoleh dari hasil pretest, dan postest.

\section{Data kualitatif}

Data kualitatif adalah data yang tidak berupa angka yaitu data mengenai komentar pengamatan pada lembar observasi berdasarkan keterlaksanaan aktivitas guru dan peserta didik selama tiga kali pertemuan, dan jawaban peserta didik berdasarkan LKPD yang mengacu pada tingkatan kemampuan literasi sains (nominal, fungsional, procedural/konseptual, multidimensional)..
Populasi yang digunakan dalam penelitian ini yaitu seluruh peserta didik kelas XI IPA B MA Muhammadiyah Al-Furqon Tasikmalaya tahun ajaran 2015/2016 yang terdiri atas dua kelas. Sampel yang akan dipilih untuk penelitian menggunakan random sampling (Sugiyono, 2013) yaitu satu kelas pada kelas XI IPA B.

\section{HASIL DAN PEMBAHASAN}

\section{Keterlaksanaan Aktivitas Guru dan Peserta didik dengan Model Pembelajaran Scientific Inquiry}

Hasil analisis menunjukkan bahwa aktivitas guru dan peserta didik pada pembelajaran menggunakan model pembelajaran Scientific Inquiry mengalami peningkatan pada setiap pertemuan. Adapun interpretasi keterlaksanaan aktivitas guru dan peserta didik secara keseluruhan dapat dilihat pada Tabel 1.

Tabel 1 menunjukkan bahwa keterlaksanaan aktivitas guru dan peserta didik dengan menggunakan model pembelajaran Scientific Inquiry mengalami peningkatan pada setiap pertemuannya dan termasuk ke dalam kategori sangat baik dengan nilai rata-rata seluruh pertemuan sebesar $84 \%$.

Tabel 1. Rekapitulasi Rata-Rata Keterlaksanaan Aktivias Guru dan Peserta didik pada Seluruh Pertemuan

\begin{tabular}{ccccc}
\hline \multirow{2}{*}{ Kegiatan } & \multicolumn{3}{c}{ Pertemuan \% } & $\begin{array}{c}\text { rata- } \\
\text { rata } \\
(\%)\end{array}$ \\
\cline { 2 - 4 } & 1 & 2 & 3 & \\
\hline $\begin{array}{c}\text { Apersepsi } \\
\text { dan Motivasi }\end{array}$ & 89 & 87 & 96 & 91 \\
\hline $\begin{array}{c}\text { Penyajian } \\
\text { Penelitian } \\
\text { Bidang }\end{array}$ & 77 & 81 & 83 & 80 \\
\hline $\begin{array}{c}\text { Identifikasi } \\
\text { Masalah }\end{array}$ & 77 & 81 & 83 & 80 \\
\hline $\begin{array}{c}\text { Pemecahan } \\
\text { Masalah }\end{array}$ & 82 & 81 & 84 & 83 \\
\hline Uji Coba & 76 & 83 & 93 & 84 \\
\hline Kegiatan & 80 & 84 & 90 & 85 \\
\hline
\end{tabular}




\begin{tabular}{|c|c|c|c|c|}
\hline \multirow{2}{*}{ Kegiatan } & \multicolumn{3}{|c|}{ Pertemuan \% } & \multirow{2}{*}{$\begin{array}{l}\text { rata } \\
\text { rata } \\
(\%)\end{array}$} \\
\hline & 1 & 2 & 3 & \\
\hline \multicolumn{5}{|l|}{ Akhir } \\
\hline rata-rata & 80 & 83 & 88 & 84 \\
\hline
\end{tabular}

Pada tahap pertama yaitu penyajian bidang penelitian, pada tahap ini guru menyajikan fenomena alam berupa gambar sebagai usaha untuk membangun pengetahuan awal peserta didik. Pada tahap ini peserta didik diberi rangsangan berupa pertanyaan agar lebih siap menerima konsep yang akan dipelajari. Tahap ini berlangsung dengan sangat baik setiap pertemuan.

Tahap kedua identifikasi masalah, peserta didik berhadapan dengan beberapa kesulitan yang harus mereka atasi, guru memberikan suatu permasalahan kepada peserta didik dengan memberikan pertanyaan yang harus diidentifikasi, sehingga peserta didik diberikan kesempatan untuk berfikir ilmiah dalam memprediksi pertanyaan yang diberikan. Dan berspekulasi mengenai demonstrasi yang akan dilakukan pada tahap selanjutnya. Tahap ini terlaksana dengan sangat baik setiap pertemuan.

Tahap ketiga yaitu pemecahan masalah, pada tahap ini guru melakukan demonstrasi untuk menguji kebenaran prediksi peserta didik pada tahap identifikasi masalah dengan memberikan sebuah pertanyaan. Pada tahap ini keterlaksanaan aktivitas guru dan peserta didik terlaksana dengan kategori sangat baik, seluruh peserta didik menjawab pertanyaan sesuai dengan instruksi guru.

Tahap yang ke empat yaitu uji coba, pada tahap ini peserta didik melakukan percobaan sendiri untuk membuktikan kebenaran dari konsep dan pengetahuan yang dimilikinya, sehingga menghasilkan data dan dapat membuat kesimpulan ilmiah serta mengkomunikasikannya sebagai salah satu aspek penting kecakapan hidup. Tahap ini merupakan tahapan dengan tingkat keterlaksanaan tinggi dibanding tahapan lain. Hal in karena guru tidak terlalu banyak terlibat dalam tahap ini, hanya peserta didik saja yang melakukan percobaan kemudian guru memperhatikan peserta didik. Peserta didik pada langkah uji coba melakukan suatu percobaan secara berkelompok. Karena dilakukan secara bersama maka peserta didik dapat saling membantu dalam menyelesaikan percobaan dan permasalahn yang muncul sehingga percobaan dapat dilaksanakan dengan baik.

\section{Peningkatan Kemampuan Literasi Sains Peserta Didik}

\section{a. Analisis Skor $\mathbf{N}$-Gain}

Besarnya peningkatan kemampuan literasi sains peserta didik berdasarkan nilai pretest dan posttest disajikan pada tabel berikut:

Tabel 2. Skor Pretest, Posttest, dan Normal Gain

\begin{tabular}{ccccc}
\hline & Pretest & Posttest & $N$-Gain & Interpretasi \\
\hline $\begin{array}{c}\text { Rata- } \\
\text { rata }\end{array}$ & 39 & 79 & 0.67 & Sedang \\
kelas & & & & \\
\hline
\end{tabular}

Berdasarkan Tabel 2. di atas diketahui bahwa peningkatan kemampuan literasi sains peserta didik setelah penerapan model pembelajaran Scientific Inquiry pada sub materi pokok fluida dinamis termasuk dalam kategori sedang dengan nilai rata-rata $N$-gain sebesar 0,67 . Peningkatan tersebut dapat digambarkan pada diagram batang berikut.

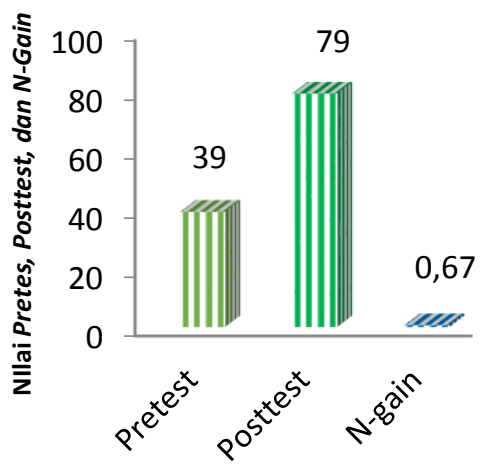

Gambar 1. Nilai Pretest, Posttest dan N-Gain Adapun data peningkatan kemampuan literasi sains pada setiap peserta didik dengan presentase sebagai berikut. 
Tabel 3. Persentase Peningkatan

Kemampuan Literasi Sains Peserta Didik pada Setiap

\begin{tabular}{|c|c|c|c|c|}
\hline \multirow{3}{*}{$\begin{array}{c}\text { Aspek } \\
\text { Literasi } \\
\text { Sains } \\
\end{array}$} & \multicolumn{3}{|c|}{ Aspek } & \multirow{3}{*}{$\begin{array}{l}\text { Inter- } \\
\text { pretas }\end{array}$} \\
\hline & \multicolumn{3}{|c|}{ Rata-rata } & \\
\hline & $\begin{array}{l}\text { Pre } \\
\text { test }\end{array}$ & $\begin{array}{l}\text { Post } \\
\text { Test }\end{array}$ & $\begin{array}{c}N- \\
\text { Gain }\end{array}$ & \\
\hline \multirow{2}{*}{ Konten } & 35 & 83 & 0.62 & Sedang \\
\hline & 52 & 95 & 0.72 & Sedang \\
\hline \multirow{2}{*}{ Konteks } & 38 & 85 & 0.64 & Sedang \\
\hline & 49 & 89 & 0.63 & Sedang \\
\hline \multirow{2}{*}{$\begin{array}{c}\text { Kompete } \\
\text { nsi }\end{array}$} & 43 & 94 & 0.74 & Sedang \\
\hline & 43 & 88 & 0.65 & Sedang \\
\hline $\begin{array}{l}\text { Rata- } \\
\text { rata }\end{array}$ & 43 & 89 & 0.67 & Sedang \\
\hline
\end{tabular}

Dari tabel 3. diatas memperlihatkan bahwa skor pretest, posttest, dan $N$-Gain untuk tiap indikator kemampuan literasi sains dari tiga aspek literasi sains yang terdiri dari enam indikator, terdapat satu indikator yang memiliki $\mathrm{N}$-Gain terendah dan tertinggi. Indikator yang memiliki $\mathrm{N}$-Gain terendah yaitu indikator kesatu pada aspek konten dengan indikator memahami fenomena alam berupa fakta, konsep dan teori mengenai asas Kontinuitas. Peserta didik terbiasa menghafal rumus dan menghitung tanpa memahami bagaimana pengaplikasiannya dalam kehidupan sehari-hari, sehingga ketika terdapat pertanyaan yang berkaitan dengan langkahlangkah yang harus dilakukan untuk mengetahui fenomena asas Kontinuitas yang berhubungan dengan penerapannya dalam kehidupan seharihari peserta didik merasa kesulitan. N-Gain tetinggi yaitu menarik kesimpulan berdasarkan data yang berkaitan dengan asas Kontinuitas. Hal ini karena ketika pembelajaran peserta didik mempelajari rumus dengan pengaplikasiannya dalam kehidupan sehari-hari, sehingga lebih mudah dalam memahami.

Analisis jawaban peserta didik berdasarkan kategori jawaban literasi sains mengalami peningkatan dari tingkat nominal menjadi multidimensional, adapun peningkatannya dapat dilihat ada tabel 4 sebagai berikut.

Tabel 4. Hasil Peningkatan Jawaban Kemampuan Literasi Sains Peserta Didik

\begin{tabular}{cc}
\hline Kategori Jawaban Literasi & $\begin{array}{c}\text { Persentase } \\
\text { (\%) }\end{array}$ \\
\hline Nominal - Fungsional & 21 \\
\hline Nominal - Konseptual & 36 \\
\hline Fungsional - Fungsional & 11 \\
\hline Fungsional - Konseptual & 18 \\
\hline $\begin{array}{c}\text { Fungsional- } \\
\text { Multidimensional }\end{array}$ & 14 \\
\hline Jumlah & 100 \\
\hline
\end{tabular}

Dari tabel 4. diatas, dapat disimpulkan bahwa secara keseluruhan terjadi peningkatan literasi sains, untuk peningkatan literasi sains dari kategori nominal-konseptual merupakan peningkatan yang paling banyak yaitu sebanyak 10 peserta didik, kemudian yang paling sedikit yaitu yang tidak mengalami peningkatan dari kategori fungsional-fungsional sebanyak tiga peserta didik.

\section{b. Uji Normalitas}

Uji normalitas dilakukan untuk mengetahui normal atau tidaknya data, maka dilakukan uji normalitas.

Berdasarkan tabel 5, hasil analisis uji normalitas menunjukkan data pretest dan posttest berdistribusi normal dan tidak normal. Oleh karena itu, maka dilakukan uji hipotesis dengan menggunakan uji Wilcoxon.

Tabel 5. Rekapitulasi Pengujian Normalitas Data Pretest dan Posttest dengan Chi Kuadrat

\begin{tabular}{lll}
\hline Keterangan & Pretest & Posstest \\
\hline Jumlah $(\mathrm{N})$ & 28 & 28 \\
\hline $\begin{array}{l}\text { Derajat } \\
\text { Kebebasan }(d k)\end{array}$ & 6 & 6 \\
\hline$x^{2}$ hitung & 9.20 & 57.75 \\
\hline$x_{\text {tabel }}$ & 11.07 & 11.07 \\
\hline Hasil & $\begin{array}{l}x^{2}{ }_{\text {hitung }} \\
x^{2} \text { tabel }\end{array}$ & $\begin{array}{l}x^{2} \text { hitung } \\
x_{\text {tabel }}^{2} \quad>\end{array}$ \\
\hline Kriteria & $\begin{array}{l}\text { Berdistribusi } \\
\text { Normal }\end{array}$ & $\begin{array}{l}\text { Berdistribusi } \\
\text { Tidak Normal }\end{array}$ \\
\hline
\end{tabular}




\section{c. Uji Hipotesis}

Uji hipotesis dilakukan untuk menguji diterima atau ditolaknya hipotesis penelitian yang diajukan. Pada penelitian ini, uji hipotesis dilakukan dengan menggunakan statistik non parametris yaitu uji Wilcoxon. Hal ini didasarkan pada hasil uji normalitas yang menunjukkan bahwa data sampel berasal dari populasi yang terdistribusi normal dan tidak normal. Rekapitulasi hasil analisisnya dapat dilihat pada tabel berikut:

Tabel 6. Rekapitulasi Hasil Uji Hipotesis (Uji Wilcoxon)

\begin{tabular}{cc}
\hline $\begin{array}{c}\text { Keterangan } \\
\text { Jumlah peserta didik } \\
(\mathrm{N})\end{array}$ & Nilai \\
\hline$\mu_{T}$ & 189 \\
\hline$\sigma_{T}$ & 40,657 \\
\hline Z $_{\text {hitung }}$ & 4,65 \\
\hline$Z_{\text {tabel }}$ & 1,69 \\
\hline A & $5 \%(0,05)$ \\
\hline Hasil & $\mathrm{Z}_{\text {hitung }}>\mathrm{Z}_{\text {tabel }}$ \\
\hline
\end{tabular}

Berdasarkan Tabel 6. di atas, hasil analisis uji Wilcoxon menunjukan bahwa nilai $Z_{\text {hitung }}$ lebih besar dari pada nilai $Z_{\text {tabel }}$ $\left(Z_{\text {hitung }}>Z_{\text {tabel }}\right)$. Dari data tersebut dapat diketahui bahwa $\mathrm{H}_{0}$ di tolak $\mathrm{H}_{\mathrm{a}}$ diterima, hal ini menunjukkan bahwa penerapan model pembelajaran Scientific Inquiry dapat meningkatkan kemampuan literasi sains peserta didik kelas XI IPA B di MA Muhammadiyah AlFurqon Tasikmalaya pada sub materi pokok fluida dinamis.

\section{KESIMPULAN}

Penelitian telah dilakukan di MA Muhammadiyah Al-Furqon Tasikmalaya Kelas XI
IPA B mengenai penerapan model pembelajaran Scientific Inquiry untuk meningkatakan kemampuan literasi sains peserta didik pada sub materi pokok fluida dinamis. Keterlaksanaan pembelajaran dengan menggunakan model pembelajaran Scientific Inquiry berdasarkan hasil analisis lembar observasi diperoleh bahwa aktivitas guru dan peserta didik selama proses pembelajaran berlangsung sebanyak tiga kali pertemuan mengalami peningkatan pada tiap pertemuan. Rata-rata aktivitas guru terkategori sangat baik, dan rata-rata aktivitas peserta didik terkategori sangat baik.

Dari hasil analisis didapatkan kemampuan literasi sains peserta didik setelah pembelajaran dengan menerapkan model pembelajaran Scientific Inquiry mengalami peningkatan. Hal ini dibuktikan dengan hasil pretest dan posttest serta nilai $\mathrm{N}$-Gain peserta didik terkategori sedang. Selain itu, peningkatan kemampuan literasi sains berdasarkan kategori jawaban literasi sains mengalami peningkatan dari kategori nominal menjadi kategori multidimensional.

\section{DAFTAR PUSTAKA}

Budiman, Noprijal. 2015. Penerapan Model Pembelajaran Scientific Inquiry untuk Meningkatkan Keterampilan Proses Sains Peserta didik pada Materi Pengukuran. Bandung: Skripsi Pendidikan Fisika UIN SGD Bandung. Tidak diterbitkan.

Grigg, dkk.,. 2013. Effect of two Scientific Inquiry Profesional Development Interventions on Teaching Practice. Universitas of Winconsin Madison: Journal Education Evaluation and Policy Analysis. Vol. 35, No. 1. [online]. Tarakan: Downloaded from http://eepa.aera.net at Universitas Pendidikan Indone on November 03 2015.

Hussain, dkk. 2011. Physic Teaching Methods: Scientific Inquiry Vs Tradisional Lecture. University of Education Pakistan: International Journal of Humanities and 
Social Science. Vol.1, No. 19. [online]. Tersedia: www.ijhssnet.com. Diakses tanggal 11 November 2015.

Ladachart, dan Yuenyong. 2015. Scientific Inquiry as a Means to Develop Teachers' and Supervisors' Scientific Literacy. International Journal of Science Educators and Teachers, Volume 1, Number 1, pp. 63-76.

Lederman, J.S., (2009). Teaching Scientific Inquiry: Exploration, Directed, Guided, and Opened-Ended Levels. New York: Allyn \& Bacon.

PISA, 2015, Assessing, Scientific, Reading And Mathematical Literacy. OECD Publishing. www.oecd.org/pisa/pisaproducts/pisa2 006/37464175.pdf, (24 Januari 2015).

Rahmawati, Sri Arini. 2015. Penerapan Model Pembelajaran Scientific Inquiry untuk Meningkatkan Keterampilan Generik Sains Peserta didik Pada Materi Fluida Statis. Skripsi Pendidikan Fisika UIN SGD Bandung. Tidak diterbitkan.

Sugiyono. (2013). Metode Penelitian Pendekatan Kuantitatif, Kualitatif dan R\&D. Bandung: Alfabeta

Toharudin, Hendrawati dan Rusmana. (2011). Membangun Literasi Sains Peserta Didik. Bandung: Humaniora

Wenning, C. J. 2007. Assessing inquiry skills as a component of scientific literacy. Illinois state university physics Dept. 